\title{
Nutrient uptake controls and limitation dynamics in north-east Greenland streams
}

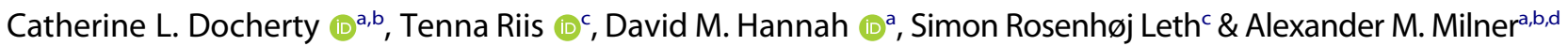 \\ aSchool of Geography, Earth and Environmental Science, University of Birmingham, Birmingham, UK; 'Department of Atmospheric \\ Environment and Aquatic Ecosystem, Institute of Mountain Science, Shinshu University, Matsumoto, Japan; 'Department of Bioscience, \\ Aarhus University, Aarhus, Denmark; 'Institute of Arctic Biology, University of Alaska, Fairbanks, AK, USA
}

\begin{abstract}
Permafrost thaw induced by climate change will cause increased release of nutrients and organic matter from the active layer to Arctic streams and, with increased water temperature, will potentially enhance algal biomass and nutrient uptake. Although essential for accurately predicting the response of Arctic streams to environmental change, knowledge of nutrient release on current Arctic in-stream processing is limited. Addressing this research gap, we quantified nutrient uptake of short-term releases of $\mathrm{NO}_{3}{ }^{-}, \mathrm{PO}_{4}{ }^{3-}$ and $\mathrm{NH}_{4}{ }^{+}$during peak snowmelt season in five streams of contrasting physiochemical characteristics (from unstable, highly turbid to highly stable, clear-water systems) in north-east Greenland to elucidate the major controls driving nutrient dynamics. Releases were plus or minus acetate to evaluate uptake dynamics with and without a dissolved organic carbon source. To substantiate limiting nutrients to algal biomass, nutrient-diffusing substrates were installed in the five streams for 16 days with $\mathrm{NH}_{4}^{+}, \mathrm{PO}_{4}{ }^{3-}$ or $\mathrm{NH}_{4}^{+}+\mathrm{PO}_{4}{ }^{3-}$ on organic and inorganic substrates. Observed low uptake rates were due to a combination of low nutrient and DOC concentrations, combined with low water temperature and primary producer biomass, and substantial variation occurred between streams. $\mathrm{N}$ was found to be the primary limiting nutrient for biofilm, whilst streams displayed widespread $\mathrm{PO}_{4}{ }^{3-}$ limitation. This research has important implications for future changes in nutrient processing and export in Arctic streams, which are predicted to include increased nutrient uptake rates due to increased nutrient availability, warmer water temperatures and increased concentration of labile carbon. These changes could have ecosystem and landscape-wide impacts.
\end{abstract}

\section{KEYWORDS}

Arctic; river; biofilm; biogeochemistry; climate change; freshwater

\section{ABBREVIATIONS}

ANOVA: analysis of variance; chl $a$ : chlorophyll $a$; DO: dissolved oxygen; DOC: dissolved organic carbon; FBOM: fine benthic organic matter; NDS: nutrientdiffusing substrates; TOC: total organic carbon

\section{Introduction}

Over the next century, a changing climate in northeast Greenland is predicted to increase winter air temperature by up to $18^{\circ} \mathrm{C}$ and total precipitation by up to $60 \%$, principally as snow in winter and rain in summer (Stendel et al. 2008). Permafrost is expected to degrade significantly, both through deepening active layer and localized thermokarst processes (Frey \& McClelland 2009; Docherty et al. 2017), with significant consequences for freshwater systems. Streams will potentially experience higher flow and water temperature, more suspended sediment and lower channel stability. Permafrost degradation is expected to lead to soil water becoming an increasingly important water source for stream ecosystems, providing nutrients and DOC previously bound within the permafrost (Madan et al. 2007; Frey \& McClelland 2009). Increased nutrient fluxes in streams are associated with increased biological activity in the biofilm (Lock et al. 1990; Hershey et al. 1997), increased by warmer water temperatures (Gíslason et al. 2000; Blaen et al. 2014), leading to an increase in nutrient uptake in headwater Arctic streams (Rasmussen et al. 2011) with consequences for the food web. However, high channel mobility and suspended sediment concentration are unfavourable to biofilm growth, and, as such, predicted decreases in channel stability could have negative impact on nutrient uptake dynamics through reductions in biofilm biomass (Ryan 1991). Headwater streams play an important role in the ecosystem by transporting nutrients and carbon to downstream rivers and oceans. In addition, because of their high surface to volume ratio, they can have a high nutrient processing capacity, converting them into major controllers of nutrient fluxes in large watersheds (Alexander et al. 2000).

The assimilation of inorganic nutrients in streams is largely undertaken by biofilms, typically comprised of both autotrophic (algae and specialized bacteria) and heterotrophic (bacteria and fungi) components, playing an important role in structuring stream food webs (Hoellein et al. 2010). Autotrophic communities are largely found on inorganic substrate (Johnson, 
Tank \& Dodds 2009), typically outcompeting heterotrophs, which are more prevalent on organic substrates because of the higher availability of labile carbon (Hoellein et al. 2010). As such, the presence of carbon can increase nutrient uptake in heterotrophic communities (Hoellein et al. 2010). As both nitrogen and phosphorous availability can limit growth of both heterotrophs and autotrophs (Pringle et al. 1986; Tank \& Webster 1998), increased concentrations of these nutrients can significantly influence community structure and function (Tank \& Dodds 2003; Cross et al. 2006). Understanding nutrient limitations to microorganisms is therefore vital in order to understand the future dynamics of nutrient processing in Arctic streams.

During the early summer snowmelt season, HighArctic streams are characterized by high hydrological connectivity with the terrestrial environment through snowmelt inputs. This input results in peak flow and peak nutrient concentration and bioavailability in the headwaters at that time of year (Holmes et al. 2008; Mann et al. 2012) and also the peak time for nutrient export to the ocean (Finlay et al. 2006; Holmes et al. 2008; Mann et al. 2012). Despite the accelerated climate change experienced in high-latitude regions, the number of studies that have examined nutrient uptake in Arctic headwater streams is limited (but see Wollheim et al. 2001; Blaen et al. 2014; Diemer et al. 2015; Schade et al. 2016).

The aim of this study was to determine the key processes involved in nutrient uptake controls and identify nutrient limitations during the peak snowmelt season across a gradient of physicochemical stream habitats associated with varying degrees of channel stability in north-east Greenland. The objectives were to elucidate: (1) reach-scale nutrient uptake rates and limitation to biofilm growth; (2) the main controls on nutrient uptake and limitation; and (3) by comparison with other studies, the wider implications of the findings in the Pan-Arctic region with respect to the effect of a changing climate on nutrient dynamics. We hypothesized that: (1) nutrient uptake would occur in all streams due to low nutrient availability in Arctic tundra ecosystems (Madan et al. 2007; Kelley \& Epstein 2009); (2) nutrient uptake would increase in the presence of a carbon source by increasing DOC availability needed for heterotrophic activity (Hoellein et al. 2010); (3) nutrient uptake would be highest in streams with warmer water temperature because of enhanced algal growth (Gíslason et al. 2000; Blaen et al. 2014); and (4) biofilm biomass would be highest in the most stable stream channels, where channel mobility and suspended sediment concentration were lower and so more favourable to primary producer growth (Ryan 1991).

\section{Methods}

\section{Study site}

The study streams were accessible from the Zackenberg research station $\left(74^{\circ} 28^{\prime} \mathrm{N}, 20^{\circ} 34^{\prime} \mathrm{W}\right)$, within Northeast Greenland National Park in the High-Arctic climatic zone (Fig. 1). Although not connected to the ice sheet approximately $60 \mathrm{~km}$ away, a number of small, high-altitude glaciers are present in the area. The mean annual air temperature is $-9.1^{\circ} \mathrm{C}$, the warmest month being July (mean $5.8^{\circ} \mathrm{C}$ ), and annual precipitation is $261 \mathrm{~mm}$, falling mainly as snow (Hansen et al. 2008). Altitude varies between 0 and $1450 \mathrm{~m}$ a.s.l with glacial plateau occurring above $1000 \mathrm{~m}$ a.s.l and a wide horizontal valley caused by glacial erosion below (Mernild et al. 2007). The valley is in a zone of continuous permafrost with active layer thickness varying between 30 and $65 \mathrm{~cm}$ (Christiansen et al. 2008).

Five streams were selected in early July 2014. All streams were fed by snowmelt representing a gradient of physicochemical variables, from low channel stability with high turbidity to high channel stablity with low turbidity. Larger snowpacks were evident in the streams Aucellaelv and Palnatokeelv than Kærelv and Grænseelv. A small snowpack was directly upstream of Unnamed, but also received input from proximal larger snowpacks. Palnatokeelv and Aucellaelv in addition received glacial meltwater, but this contribution was minimal during the study period. Kærelv, Grænseelv and Unnamed supported vegetated banks, whereas the banks of Aucellaelv and Palnatokeelv were unvegetated and these streams showed high channel mobility and braiding. Water sources for Aucellaelv and Palnatokeelv originated at a higher altitude and mobilized a large amount of sediment. Study reaches were limited to approximatetely $100 \mathrm{~m}$ in length to ensure all study reaches were single channels with no connecting tributaries. Experiments were undertaken within a 10 -h period between 12 and 20 July 2014 .

\section{Stream characteristics and environmental variables}

Air temperature and precipitation data were obtained from a weather station located within $5 \mathrm{~km}$ of the study streams maintained by the Greenland Ecosystem Monitoring Programme. All climate data were recorded every $30 \mathrm{~min}$, except precipitation, which was recorded hourly.

Data loggers (TinyTag Aquatic 2 TG-4100, Gemini) recorded water temperature every $30 \mathrm{~min}$ at the study streams from 11 July to 15 September and water velocity was measured using a hand-held flow meter ( $\mu \mathrm{P}$-TAD, Höntzsch). The entire 


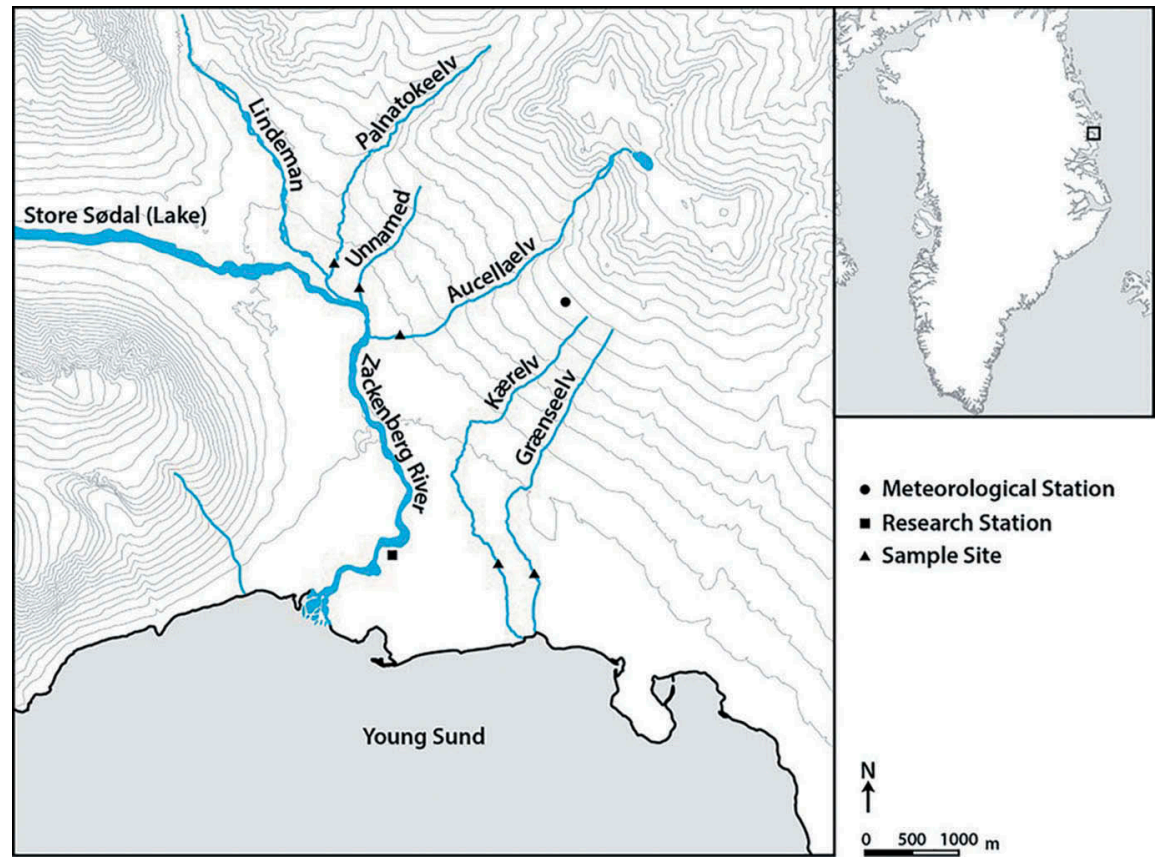

Figure 1. Location of the five study streams and associated nutrient uptake experiments.

Pfankuch Index (Pfankuch 1975) was calculated at each site as a measure of channel stability. Ambient nutrient concentrations were measured at all sites using a Lachat QuikChem flow injection analyser (Lachat Instruments, APC Bioscientific Limited, England; APHA 2012).

Suspended sediment was estimated by filtering $1 \mathrm{~L}$ of stream water through pre-weighed $\mathrm{GF} / \mathrm{F}$ filter papers, dried at $60^{\circ} \mathrm{C}$ for $48 \mathrm{~h}$ and then re-weighed. Suspended TOC was measured using a TOC-V CPH analyser (Shimadzu).

Sediment respiration was measured as a proxy for heterotrophic activity where three samples from areas of fine sediment were collected and placed in a container along with $500 \mathrm{ml}$ of filtered stream water with no headspace remaining in the container. DO was measured with an optical dissolved oxygen instrument (ProODO) in the container, the sample was stored at $5^{\circ} \mathrm{C}$ in the dark for $24 \mathrm{~h}$ until DO was remeasured. The sediment was dried at $105^{\circ} \mathrm{C}$ for $48 \mathrm{~h}$ to give the units $\mu \mathrm{g} \mathrm{O}_{2} / \mathrm{g}$ of sediment/h.

FBOM $(<1 \mathrm{~mm}$ in size) was estimated at each site using an open-ended PVC cylinder $(16 \mathrm{~cm}$ diameter; $201 \mathrm{~cm}^{2}$ area) inserted into the sediment. The sediments were lightly disturbed by hand down to approximately $2 \mathrm{~cm}$ depth. The water in the cylinder was then mixed and a $200 \mathrm{ml}$ sample filtered onto a pre-combusted Whatman GF/C filter paper in the laboratory before combustion at $480^{\circ} \mathrm{C}$ to obtain ash-free dry mass to estimate organic matter content (Wallace et al. 2007).

Chl $a$ was measured as a proxy for benthic algae biomass and determined for two substrate types: stone and gravel. Five stone samples ( $>6 \mathrm{~cm} \mathrm{~b}$-axis) and gravel samples $\left(200 \mathrm{~cm}^{2}\right.$ core to collect upper gravel layer from stream bed) were collected. In the laboratory, a toothbrush removed biofilm onto a Whatman GF/C filter paper and was frozen before chl $a$ extraction in $96 \%$ ethanol and absorbance measured at 665 and $750 \mathrm{~nm}$ using a spectrophotometer (UV 1700 Spectrophotometer, Shimadzu). Chl $a$ biomass was calculated as:

$$
\text { Chl } a=\frac{\left(A b s_{665}-A b s_{750}\right) * E}{83.4 * A * 10^{-4}},
$$

where $E$ is volume of ethanol $(\mathrm{ml}), 83.4$ is the absorption of chl $a$ in ethanol, $A$ is the sample area $\left(\mathrm{cm}^{2}\right)$ and $10^{-4}$ is the conversion factor from $\mathrm{cm}^{2}$ to $\mathrm{m}^{2}$. Habitat weighted chl $a$ was calculated as the sum of biomass of chl $a$ on stones and gravel multiplied by the percentage of the two habitats, respectively.

\section{Nutrient uptake experiments}

Short-term nutrient experiments were undertaken at five stream sites following the protocol of Tank et al. (2007). A transect along a reach of each stream, free from tributaries, was selected with the point of nutrient injection at the upstream site. Further sites were identified along the transect length to determine change in nutrient concentration. A water sample was collected from each site prior to nutrient addition to determine ambient nutrient concentrations. A prior injection of $\mathrm{NaCl}$ was made to ascertain time to asymptote. Continuous injections of $\mathrm{NH}_{4}{ }^{+}, \mathrm{NO}_{3}{ }^{-}$, $\mathrm{PO}_{4}{ }^{3-}$ and $\mathrm{NH}_{4}{ }^{+}$with acetate as a carbon source diluted in $8 \mathrm{~L}$ of stream water were made at each site using a peristaltic pump with a flow rate of $100 \mathrm{ml} /$ min. Nutrient concentration levels were increased above ambient by $15 \mu \mathrm{gL}^{-1}\left(\mathrm{NH}_{4}^{+}\right), 20 \mu g \mathrm{~L}^{-1}$ 
$\left(\mathrm{NO}_{3}{ }^{-}\right), 30 \mu \mathrm{gL}^{-1}\left(\mathrm{PO}_{4}{ }^{3-}\right)$ and $100 \mu \mathrm{g} \mathrm{L}{ }^{-1}$ for acetate (see Blaen et al. 2014). Bromide (Br) was added as a conservative tracer and concentrations measured at each site. Water samples were collected from each of the designated sampling sites at the following distances from the injection site: $10 \mathrm{~m}, 20 \mathrm{~m}, 35 \mathrm{~m}$, $50 \mathrm{~m}, 70 \mathrm{~m}, 90 \mathrm{~m}, 107 \mathrm{~m}$. However, the final sampling site was shorter in some streams to avoid the influence of tributaries; in Unnamed the final site was at $103 \mathrm{~m}$ from the injection site and in Aucellaelv the final site was at $97 \mathrm{~m}$. In Palnatokeelv, on account of braiding and tributaries, the sampling transect was shorter and samples were collected every $10 \mathrm{~m}$ up until $65 \mathrm{~m}$ distance from the injection site. In all streams, the water travelling time was $15-25 \mathrm{~min}$. Water samples were filtered through Whatman GF/ F $0.7 \mu \mathrm{m}$ filter papers in the field and frozen within 8 h. Possible downstream dilution was taken into account by dividing the increase in nutrient concentration by the increase in $\mathrm{Br}^{-}$concentration between ambient and raised levels.

Nutrient uptake length $\left(S_{w}, m\right)$, velocity $\left(V_{f}, m\right.$ $\left.\min ^{-1}\right)$ and areal uptake rate $\left(\mathrm{U}, \mathrm{mg} \mathrm{m}^{-}{ }^{2} \mathrm{~min}^{-1}\right)$ were determined using standard protocols (Tank et al. 2007) based on the longitudinal decrease in nutrient concentration along the study reaches, discharge and stream width. Water samples were analysed for $\mathrm{NH}_{4}{ }^{+}$, $\mathrm{NO}_{3}{ }^{-}$and $\mathrm{PO}_{4}{ }^{3-}$ using the hypochlorite, cadmium reduction and ascorbic acid methods, respectively, on a Lachat QuikChem flow injection analyser. Bromide concentrations were determined using ion-chromatography (Dionex Ionchromatograph system 2500, Thermo Fisher Scientific).

\section{NDS experiments}

To determine nutrient limitation at each stream site to autotrophic growth, Polycon cups were filled with $0.2 \%$ agar solution combined with one or more nutrients on either a glass disc (inorganic substrate) or cellulose sponge (organic substrate) to act as different substrate types for biofilm colonization, following Tank et al. (2007). There were four treatments with five replicates: (1) $\mathrm{NH}_{4}{ }^{+}$additions $\left(0.5 \mathrm{M} \mathrm{NH} \mathrm{NH}_{4} \mathrm{Cl}\right)$; (2) $\mathrm{PO}_{4}{ }^{3-}$ additions $\left(0.5 \mathrm{M} \mathrm{KH}_{2} \mathrm{PO}_{4}\right)$; (3) combined $\mathrm{NH}_{4}{ }^{+}$ $+\mathrm{PO}_{4}{ }^{3+}$ additions $\left(0.5 \mathrm{M} \mathrm{NH} \mathrm{Nl}_{4}+0.5 \mathrm{M} \mathrm{KH}_{2} \mathrm{PO}_{4}\right)$; and (4) controls with agar only and no added nutrient. The 20 cups per stream were organized into four rows in plastic racks and secured in place on the stream bed by rocks. After 16 days, the cups were removed and substrates (glass discs and cellulose sponge) were contained within plastic bags along with the associated stream water and frozen until analysis for chl $a$. In the laboratory, $4 \mathrm{ml}$ of $96 \%$ ethanol was added to the bags for $12 \mathrm{~h}$ before measuring absorbance at 665 and $750 \mathrm{~nm}$ (UV 1700 spectrophotometer, Shimadzu).

\section{Data analysis}

A climate graph was constructed to show air temperature and precipitation during the field campaign. Differences in water temperature between streams were tested by one-way ANOVA on data collected every 30 minutes between 11 July and 15 September. One-way ANOVAs followed by Tukey post hoc tests on significant results were conducted to ascertain differences in background nutrient concentrations between all streams and chl $a$ biomass on stone and gravel. Spearman's rank correlation analysis was conducted to test for associations between environmental variables and background nutrients, and between different environmental variables. The environmental variables included were: discharge, water temperature, channel stability, FBOM, organic matter content, TOC, chl $a$, sediment respiration and dissolved oxygen. One-way ANOVAs were conducted to ascertain differences in FBOM, organic matter, sediment respiration and habitat weighted chl $a$ between streams. Other environmental variables were not tested for differences between streams because of a lack of repetitions. The ratio of $\mathrm{NH}_{4}{ }^{+}: \mathrm{NO}_{3}{ }^{-}$was calculated to visualize the relative importance of autotrophic and heterotrophic activity in driving stream metabolism, where a high ratio of $\mathrm{NH}_{4}{ }^{+}: \mathrm{NO}_{3}{ }^{-}$combined with undersaturation of dissolved oxygen suggests heterotrophic activity dominates stream metabolism (Schade et al. 2016). The $\mathrm{NH}_{4}{ }^{+}: \mathrm{NO}_{3}{ }^{-}$results are intended to be taken as a guidance on metabolic conditions; however, they should be interpreted with caution because of the possibility of concentrations being transported from other areas upstream.

Spearman's rank correlation analysis was conducted to test for associations between uptake parameters and the previously mentioned environmental variables. Two-way ANOVAs were undertaken for the NDS to determine limiting nutrients. There was limitation of a single nutrient if there was a significant result for one of the single nutrient additions compared to the control, and a co-limitation of both $\mathrm{N}$ and $\mathrm{P}$ if there was a significant result for interaction or for both nutrients added separately compared to the control (Tank \& Dodds 2003). For all analyses, results were first analysed for homogeneity of variance using Levene's test, and if they were found to not be homogeneous, data were log transformed before further analysis. The R environment was used for all statistical analysis and graphical representation of data.

\section{Results}

\section{Stream characteristics and environmental variables}

Maximum air temperature during the field campaign was $15^{\circ} \mathrm{C}$, with a minimum of $-4.0^{\circ} \mathrm{C}$. Two rainstorm 


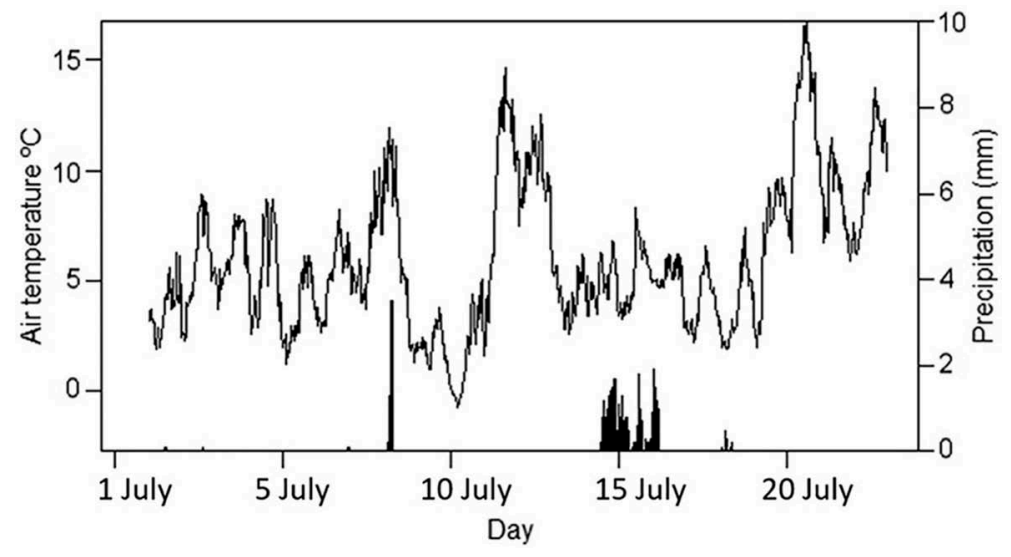

Figure 2. Air temperature (line) and precipitation (bars) during the field campaign.

events occurred: $5 \mathrm{~mm}$ fell on 8 July and $31.1 \mathrm{~mm}$ fell from 14 to 16 July (Fig. 2). Mean water temperature during summer 2014 (11 July-15 September) varied between $3.33^{\circ} \mathrm{C}$ and $5.55^{\circ} \mathrm{C}$. Water temperature was significantly different between all streams, except for Kærelv and Unnamed (Table 1). Palnatokeelv was not

Table 1. F values from one-way ANOVAs for water temperature between streams during the period 11 July to 15 September. Df $=(1,6358)$.

\begin{tabular}{|c|c|c|c|c|}
\hline & Kærelv & Grænseelv & Aucellaelv & Unnamed \\
\hline $\begin{array}{l}\text { Kærelv } \\
\text { Grænseelv } \\
\text { Aucellaelv } \\
\text { Unnamed }\end{array}$ & & $46.1^{a}$ & $\begin{array}{l}743.8^{a} \\
459.3^{a}\end{array}$ & $\begin{array}{c}- \\
70.6^{a} \\
844.3^{a}\end{array}$ \\
\hline
\end{tabular}

included because of a missing data logger. Lower channel stability (Pfankuch Index), higher bed mobility and higher suspended sediment were found in the streams with the largest snowpacks related to larger spring floods and increased nivation processes, such as pronival solifluction and the accumulation of alluvial fans (Table 2). For bed substrate, equal amounts of gravel and stone were found at Kærelv whilst Grænseelv was predominantly gravel. Palnatokeelv, Unnamed and Aucellaelv bed substrate was predominantly stone (Table 2). Mean suspended sediment was low in Kærelv, Grænseelv and Unnamed (between 0.5 and $7.3 \mathrm{mg} \mathrm{L}^{-1}$ ) but high in Palnatokeelv (96.3 $\left.\mathrm{mg} \quad \mathrm{L}^{-1}\right)$ and Aucellaelv $\left(1120.3 \mathrm{mg} \mathrm{L}^{-1}\right)$. Stream discharge ranged between

Table 2. Environmental characteristics and background nutrient concentrations of the five study streams. DO measurements are all from 2015. All other conditions measured on day of sampling. Superscript letters indicate significant differences $(p<0.05)$ between pairs of streams.

\begin{tabular}{|c|c|c|c|c|c|c|}
\hline \multicolumn{2}{|c|}{ Environmental variable } & \multirow{2}{*}{$\frac{\text { Kærelv }}{151}$} & \multirow{2}{*}{$\begin{array}{c}\text { Grænseelv } \\
189\end{array}$} & \multirow{2}{*}{$\frac{\text { Unnamed }}{204}$} & \multirow{2}{*}{$\frac{\text { Aucellaelv }}{580}$} & \multirow{2}{*}{$\frac{\text { Palnatokeelv }}{247}$} \\
\hline Discharge & $\mathrm{L} / \mathrm{s}$ & & & & & \\
\hline Channel width & $\mathrm{m}$ & 3.2 & 2.6 & 4 & 2.8 & 2.4 \\
\hline Electrical conductivity & $\mu S \mathrm{~cm}^{-1}$ & 54 & 93.1 & 88.3 & 192.4 & 58 \\
\hline Water temperature & ${ }^{\circ} \mathrm{C}$ & $7.2^{\mathrm{a}, \mathrm{b}}$ & $4^{a, b, c}$ & $12.1^{\mathrm{C}}$ & $5.8^{\mathrm{a}, \mathrm{b}, \mathrm{c}}$ & 7 \\
\hline DO & $\%$ & 76.5 & 78 & 88 & 75.1 & 77.8 \\
\hline Pfankuch Index & & 74 & 78 & 113 & 116 & 114 \\
\hline Suspended sediment & $\mathrm{mg} \mathrm{L}^{-1}$ & 5.1 & 7.3 & 0.5 & 1120.3 & 96.3 \\
\hline \multirow[t]{2}{*}{ Dominant bed sediment types } & $\%$ stone $(>6 \mathrm{~cm})$ & 31.3 & 31.6 & 66.7 & 79.4 & 71.6 \\
\hline & $\%$ gravel $(2-6 \mathrm{~cm})$ & 29.8 & 42.4 & 20.7 & 15.5 & 13.8 \\
\hline Moss coverage & $\%$ & 2.6 & 1.9 & 2 & - & - \\
\hline \multirow[t]{2}{*}{ FBOM } & $\mathrm{g} \mathrm{m}^{-2}$ & 8.11 & 21.47 & 19.67 & 25.94 & 19.35 \\
\hline & SD & 2.04 & 2.67 & 8.14 & 8.28 & 4.93 \\
\hline \multirow[t]{2}{*}{ Organic matter } & $\%$ & $4.01^{\mathrm{C}}$ & $2.48^{c}$ & $9.09^{c}$ & $5.01^{c, d}$ & $5.84^{\mathrm{c}, \mathrm{d}}$ \\
\hline & SD & 1.34 & 0.77 & 2.37 & 0.76 & 1.06 \\
\hline \multirow[t]{2}{*}{ Sediment respiration } & $\mathrm{mg} \mathrm{O}_{2} \mathrm{ml}^{-1}$ sediment/day & 3.43 & 2.61 & $1.86^{\mathrm{e}}$ & $1.52^{\mathrm{e}}$ & $4.31^{\mathrm{e}}$ \\
\hline & SD & 1.09 & 0.12 & 0.33 & 0.17 & 0.94 \\
\hline \multirow[t]{2}{*}{ Habitat weighted $\mathrm{Chl} a$} & $\mu \mathrm{g} \mathrm{m}^{-2}$ & 163.49 & 110.25 & 218.95 & 131.92 & 124.8 \\
\hline & SD & 73.63 & 72.27 & 91.73 & 187.88 & 118.87 \\
\hline \multirow[t]{2}{*}{ TOC } & $\mathrm{mg} \mathrm{L}^{-1}$ & 2.14 & 2.79 & 2.93 & 7.76 & 1.11 \\
\hline & SD & 0.06 & 0.1 & 0.3 & 1.15 & 0.04 \\
\hline \multirow[t]{2}{*}{$\mathrm{PO}_{4}{ }^{3+}$} & $\mu \mathrm{g} \mathrm{L}^{-1}$ & $3.98^{\mathrm{a}, \mathrm{b}, \mathrm{d}, \mathrm{e}}$ & $1.51^{\mathrm{a}, \mathrm{b}, \mathrm{c}, \mathrm{d}, \mathrm{e}}$ & $2.45^{b, c, d, e}$ & $4.18^{\mathrm{a}, \mathrm{b}, \mathrm{c}, \mathrm{d}}$ & $4.01^{a, b, c, e}$ \\
\hline & SD & 0.003 & 0.004 & 0.0004 & 0.002 & 0.009 \\
\hline \multirow[t]{2}{*}{$\mathrm{NH}_{4}^{+}$} & $\mu \mathrm{g} \mathrm{L}^{-1}$ & $14.53^{d}$ & $7.47^{d}$ & $6.7^{\mathrm{d}}$ & $33.81^{d}$ & $12.48^{d}$ \\
\hline & SD & 0.006 & 0.002 & 0.002 & 0.007 & 0.004 \\
\hline \multirow[t]{2}{*}{$\mathrm{NO}_{3}{ }^{-}$} & $\mu \mathrm{g} \mathrm{L}^{-1}$ & $<0.001^{d}$ & $0.36^{d}$ & $0.06^{\mathrm{d}, \mathrm{e}}$ & $50.66^{\mathrm{d}, \mathrm{e}}$ & $11.79^{\mathrm{d}, \mathrm{e}}$ \\
\hline & SD & 0.001 & 0.001 & 0.001 & 0.012 & 0.008 \\
\hline $\mathrm{NH}_{4}{ }^{+}: \mathrm{NO}_{3}{ }^{-}$ & & $14,530.00$ & 20.75 & 111.67 & 0.67 & 1.06 \\
\hline
\end{tabular}


151 and $580 \mathrm{~L} / \mathrm{s}$ (Table 2). One-way ANOVA indicated significant differences in background nutrient concentrations between streams. $\mathrm{NO}_{3}{ }^{-}$concentrations showed the most variability $\left(\mathrm{F}_{(4,30)}=405.7\right.$, $p=<0.01)$, where Aucellaelv and Palnatokeelv were significantly higher than other streams $(p=<0.01)$, whilst Kærelv, Grænseelv and Unnamed were not significantly different. $\mathrm{NO}_{3}{ }^{-}$varied from below the detection limit of $0.056 \mu \mathrm{g} / \mathrm{L}$ in Unnamed to $50.66 \mu \mathrm{g} / \mathrm{L}$ in Aucellaelv. $\mathrm{PO}_{4}{ }^{3-}$ was highly variable $\left(\mathrm{F}_{(4,30)}=19.79, p=<0.01\right)$, with significant difference between all combinations of streams $(p=>0.05$ for Unnamed and Grænseelv; all other combinations $p=<0.01$ ), except for between Unnamed and Kærelv, and between Aucellaelv and Palnatokeelv, which were not significantly different. Highest concentrations were found in Aucellaelv and Palnatokeelv. $\mathrm{NH}_{4}{ }^{+}$was also variable (F $(4,30)=32.18, p=<0.01)$, and was significantly higher in Aucellaelv than the other streams $(p=<0.01)$. Ambient nutrient concentrations were not significantly correlated with any environmental variables. There was no significant correlation between any environmental variables, with the highest correlation found between channel stability and suspended sediment, and chl $a$ with water temperature (Spearman rank: $\mathrm{r}=0.9, p=0.083$ for both, $p=>0.05$ for all combinations).

Moss was present in small amounts in the three most stable streams (Kærelv, Grænseelv and Unnamed), making it a minor contributor to primary production in these systems (Table 2). Sediment respiration was significantly different between streams $\left(\mathrm{F}_{(4,10)}=5.85, p=0.01\right)$, being significantly higher in Palnatokeelv than Unnamed and Aucellaelv $(p=<0.05)$. Organic matter also varied significantly between sites $\left(\mathrm{F}_{(4,19)}=10.56, p=<0.001\right)$, where Unnamed was significantly higher than all streams ( $p=<0.05$ for all sites) and Palnatokeelv was significantly higher than Grænseelv $(p=<0.05)$ (Table 2). Benthic algae biomass was highest in Unnamed (habitat weighted: $218.95 \mu \mathrm{g} / \mathrm{m}^{2}$ ) and lowest in Grænseelv (habitat weighted: $110.25 \mu \mathrm{g} / \mathrm{m}^{2}$ ). In all streams stones were found to have larger benthic algal biomass compared to gravel, and biomass was significantly higher on both stones $\left(\mathrm{F}_{(4,18)}=4.23\right.$, $p=0.014)$ and gravel $\left(\mathrm{F}_{(4,20)}=3.33, p=0.03\right)$ in Kærelv compared to Aucellaelv (stone: $P_{\text {adj }}=0.018$, gravel: $P_{\text {adj }}=0.05$ ) and Palnatokeelv (stone: $P_{\text {adj }}=0.04$, gravel: $P_{\text {adj }}=0.03$ ) (Fig. 3). $\mathrm{NH}_{4}{ }^{+}: \mathrm{NO}_{3}{ }^{-}$ showed high ratios in the streams that had highest channel stability according to the Pfankuch index (Kærelv, Grænseelv and Unnamed), with an exceptionally high ratio found for Kærelv (14,530.00), (Table 2).

\section{Nutrient uptake experiments}

No detectable uptake of any added nutrients was observed in Grænseelv and Aucellaelv (Table 3). Detectable uptake of $\mathrm{PO}_{4}{ }^{3-}$ was found in the other three streams. Palnatokeelv was the only stream to exhibit uptake of all injected nutrients, whereas there was also detectable $\mathrm{NH}_{4}{ }^{+}$uptake in Kærelv. Upon injecting acetate alongside $\mathrm{NH}_{4}^{+}$in Palnatokeelv, uptake length declined by more than half from $92.79 \mathrm{~m}$ to $37.87 \mathrm{~m}$. The longest uptake lengths and lowest uptake velocity were for $\mathrm{PO}_{4}{ }^{3-}$ in the two streams that recorded uptake of two or more solutes (Palnatokelv and Kærelv). We did not find any

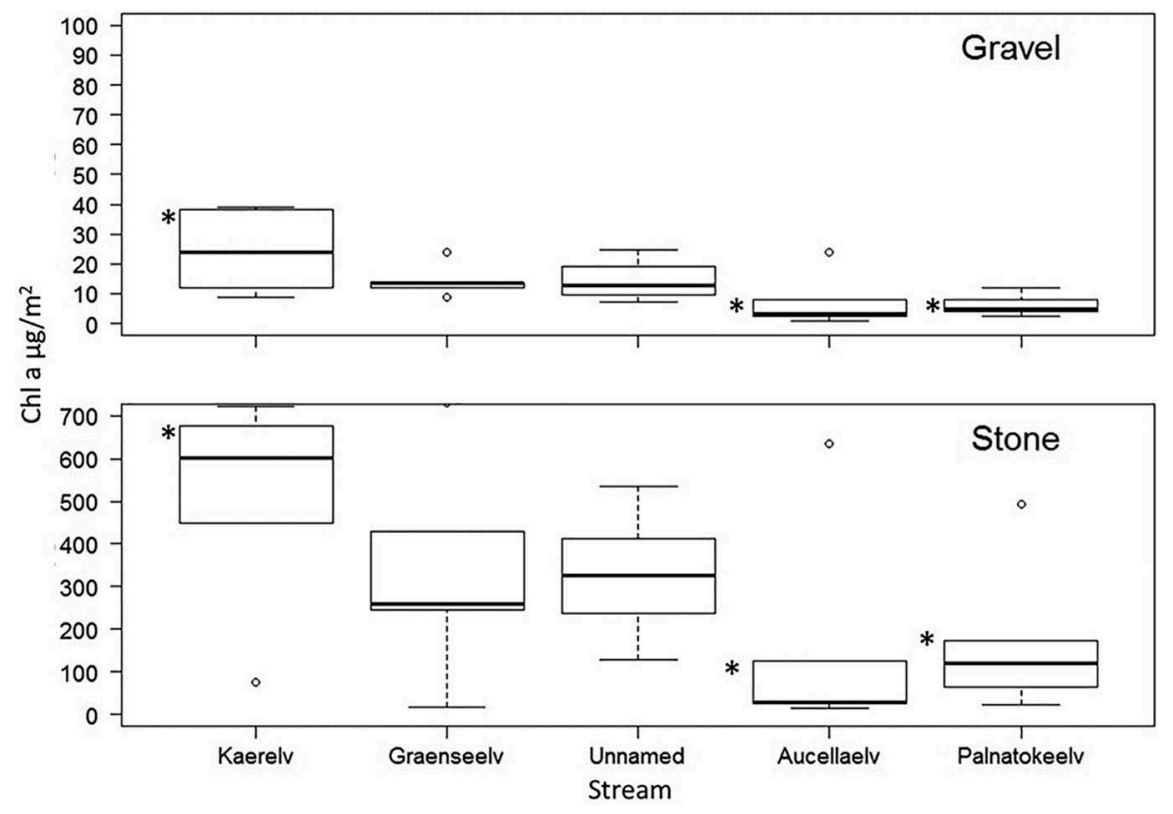

Figure 3. Chl $a$ biomass on stones and gravel in each study stream. Note different $Y$ axis scale. Asterisks highlights significant differences between streams. 
Table 3. Nutrient uptake variables during peak snowmelt period in $2014 . \mathrm{S}_{\mathrm{w}}$ in $\mathrm{m}, \mathrm{V}_{\mathrm{f}}$ in $\mathrm{m} / \mathrm{h}, \mathrm{U}$ in $\mu \mathrm{g} \mathrm{m}^{-2} \mathrm{~h}^{-1}$. No detectable uptake is indicated with a dash.

\begin{tabular}{|c|c|c|c|c|c|c|}
\hline \multirow[b]{2}{*}{ Nutrient addition } & \multirow[b]{2}{*}{ Uptake parameter } & \multicolumn{5}{|c|}{ Stream } \\
\hline & & Kærelv & Grænseelv & Unnamed & Aucellaelv & Palnatokeelv \\
\hline \multirow[t]{3}{*}{$\mathrm{PO}_{4}^{3-}$} & $\mathrm{S}_{\mathrm{w}}$ & 586.34 & - & 686.16 & - & 163.25 \\
\hline & $V_{f}$ & 0.29 & - & 0.27 & - & 2.27 \\
\hline & $\mathrm{U}$ & 0.46 & - & 0.04 & - & 0.55 \\
\hline \multirow[t]{3}{*}{$\mathrm{NH}_{4}{ }^{+}$} & $\mathrm{S}_{\mathrm{w}}$ & 192.4 & - & - & - & 92.79 \\
\hline & $V_{f}$ & 0.88 & - & - & - & 3.99 \\
\hline & $\mathrm{U}$ & 0.77 & - & - & - & 2.99 \\
\hline \multirow[t]{3}{*}{$\mathrm{NH}_{4}^{+}+$Acetate } & $S_{w}$ & - & - & - & - & 37.87 \\
\hline & $V_{f}$ & - & - & - & - & 9.78 \\
\hline & $\mathrm{U}$ & - & - & - & - & 7.33 \\
\hline \multirow[t]{3}{*}{$\mathrm{NO}_{3}^{-}$} & $S_{w}$ & - & - & - & - & 52.43 \\
\hline & $V_{f}$ & - & - & - & - & 7.07 \\
\hline & U & - & - & - & - & 4.22 \\
\hline
\end{tabular}

significant relationships between uptake parameters $(\mathrm{Sw}, \mathrm{Vf}, \mathrm{U})$ and the environmental variables listed in the data analysis section.

\section{NDS}

Heavy storm events during the field campaign removed diffusing cups in Aucellaelv and Palnatokeelv. For the other three streams, control chl $a$ biomass varied between 0.33 and $0.79 \mu \mathrm{g} / \mathrm{cm}^{2}$ on glass substrate and 0.13 and $0.27 \mu \mathrm{g} / \mathrm{cm}^{2}$ on sponge. In all three streams, highest biofilm biomass was found on glass substrate. The highest chl a biomass recorded was $1.58 \mu \mathrm{g} / \mathrm{cm}^{2}$ after $\mathrm{N}+\mathrm{P}$ addition on glass substrate in Kærelv and the lowest was $0.13 \mu \mathrm{g} / \mathrm{cm}^{2}$ in the control on sponge in Kærelv and $\mathrm{P}$ addition in Unnamed (Fig. 4). In all streams, biofilm biomass was highest when nitrogen and phosphorous were added together, and more notably so for autotrophic biofilms. Twoway ANOVA indicated nutrient limitation in all streams. Nitrogen and phosphorous were co-limiting on both substrate types in Unnamed stream and on glass in Kærelv and sponge in Grænseelv (Table 4). However, nitrogen limitation, either alone or combined with phosphorous limitation, was the most frequent significant response. Phosphorous limitation alone was only found in two cases (Table 4).

\section{Discussion}

\section{Nutrient uptake dynamics}

As nutrient uptake was not detected in Grænseelv or Aucellaelv, hypothesis 1 - that nutrient uptake would occur in all streams on account of low nutrient availability in the Arctic tundra - was not accepted. The lack of detectable uptake in these two streams could possibly be explained by low biofilm biomass or the low water temperature found in these two streams preventing detectable uptake. The large variation in

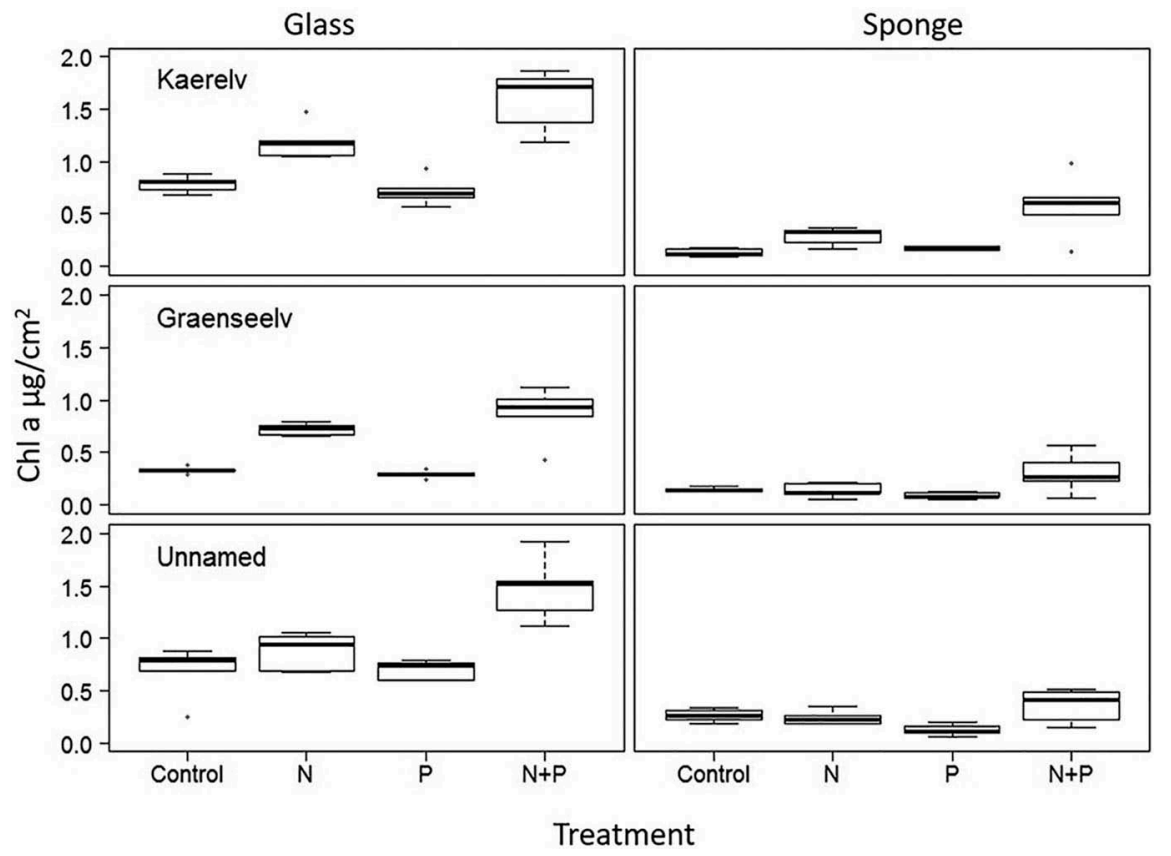

Figure 4. Chl $a$ content in biofilm following different nutrient additions after 16 days. 
Table 4. Two-way ANOVA results for NDS investigations to determine limiting or used nutrients in each stream. For all sites and substrate types $n=20 . F$ values presented. Significant $p$ values are in boldface.

\begin{tabular}{|c|c|c|c|c|}
\hline Stream & Substrate & $\mathrm{NH}_{4}^{+}$ & $\mathrm{PO}_{4}{ }^{3-}$ & $\mathrm{NH}_{4}{ }^{+*} \mathrm{PO}_{4}{ }^{3-}$ \\
\hline \multirow[t]{2}{*}{ Kærelv } & Glass & $58.65^{b}$ & 3.86 & $7.59^{a}$ \\
\hline & Sponge & $22.1^{b}$ & $4.98^{a}$ & 0.46 \\
\hline \multirow[t]{2}{*}{ Grænseelv } & Glass & $95.1^{b}$ & $<0.00$ & 2.07 \\
\hline & Sponge & 3.54 & 0.1 & $6.19^{a}$ \\
\hline \multirow[t]{2}{*}{ Unnamed } & Glass & $23.5^{b}$ & $9.4^{b}$ & $8.48^{a}$ \\
\hline & Sponge & $5.75^{a}$ & 0.06 & $8.52^{a}$ \\
\hline
\end{tabular}

${ }^{\mathrm{a}} p=<0.05 .{ }^{\mathrm{b}} p=<0.001$.

nutrient uptake between the remaining three streams was similar to findings from Siberia (Diemer et al. 2015; Schade et al. 2016) and Svalbard (Blaen et al. 2014). $\mathrm{NH}_{4}{ }^{+}$uptake was lower than observed in Siberia, but comparable to the lower uptake results from Svalbard, whilst $\mathrm{PO}_{4}{ }^{3-}$ and $\mathrm{NO}_{3}{ }^{-}$uptake were lower than other studies (Blaen et al. 2014; Diemer et al. 2015; Schade et al. 2016). With low benthic algae biomass, and moss not evident, uptake of all nutrients in Palnatokeelv was unexpected. However, high sediment respiration rates (more than twice that of other streams) and increased $\mathrm{NH}_{4}{ }^{+}$uptake when injected alongside a DOC source suggests uptake was principally by heterotrophic bacteria.

DOC uptake is known to be largely controlled by heterotrophic activity (Martí et al. 2009) in Svalbard freshwater systems (Säwström et al. 2007), whilst autotrophs obtain carbon largely from $\mathrm{CO}_{2}$ or $\mathrm{HCO}_{3}{ }^{-}$(Allen \& Spence 1981). The increased uptake alongside a DOC source indicates that biotic processes in streams in this region are potentially limited by DOC availability and highlight the coupled biogeochemical cycles of $\mathrm{N}$ and $\mathrm{C}$, as previous studies have found DOC to be a principal driver and strong control on nutrient uptake (Dodds et al. 2004; Johnson, Tank \& Arango 2009; Diemer et al. 2015; Rodríguez-Cardona et al. 2016). However, experimental additions of a carbon source alongside nutrients in Arctic tundra streams have been negligible (but see Blaen et al. 2014). Whilst the influence of DOC addition on nutrient uptake was limited to only one site, the substantial increase in uptake and decrease in uptake length supports our hypothesis that uptake would increase in the presence of a carbon source. The other two streams where uptake was observed - Unnamed and Kærelv - showed different biofilm conditions to Palnatokeelv. Unnamed was the opposite of Palnatokeelv, supporting high benthic algal and moss biomass and low sediment respiration, and so autotrophic activity was largely responsible for nutrient uptake. The dominance of autotrophic activity was confirmed for Unnamed, Kærelv and Grænseelv through the NDS experiments as biomass was highest on the inorganic substrate where heterotrophs were outcompeted. This pattern was also supported by the higher $\mathrm{NH}_{4}{ }^{+}: \mathrm{NO}_{3}{ }^{-}$ratios in Kærelv, Grænseelv and Unnamed, whilst Palnatokeelv showed a small ratio. Hence our findings indicate nutrient uptake in High-Arctic streams can be driven by heterotrophic or autotrophic processes. The proportion of nutrients sorbed to sediments was not investigated in this study. Nethertheless, the NDS experiments indicate biological uptake within the system, as does the increased uptake of $\mathrm{NH}_{4}^{+}$when injected alongside a carbon source.

In contrast to Arctic Siberia and Svalbard, $\mathrm{PO}_{4}{ }^{3-}$ was a limiting nutrient as three of the five streams showed detectable uptake. However, when $\mathrm{NH}_{4}^{+}$ uptake was evident, $\mathrm{NH}_{4}{ }^{+}$was in higher demand compared to availability than $\mathrm{PO}_{4}{ }^{3-}$, meaning that $\mathrm{NH}_{4}^{+}$was the overall primary limiting nutrient in these systems, as found in Arctic Siberia and Svalbard (Blaen et al. 2014; Schade et al. 2016). In a study from boreal Siberia, both $\mathrm{PO}_{4}{ }^{3-}$ and $\mathrm{NH}_{4}{ }^{+}$were found to be limiting in different streams (Diemer et al. 2015). The NDS experiments also suggested nitrogen to be the primary limiting nutrient in these Greenlandic systems alongside phosphorous (as was also found by Tank \& Dodds 2003). Whilst the NDS experiments test nutrient limitation in specific components of the stream ecosystem, i.e., the biofilm colonizing inorganic and organic substrate, the uptake experiments measure whole stream uptake (Tank et al. 2007). $\mathrm{N}$ may therefore be only limiting autotrophic biofilm growth, whereas heterotrophic uptake in sediment could have driven the whole reach $\mathrm{P}$ limitation. However, the lack of $\mathrm{P}$ sorption data meant that the overall role of heterotrophic uptake of $\mathrm{P}$ is uncertain. More replication of the short-term nutrient uptake experiments in different streams at different times would be required to confirm these findings.

DOC and nutrient concentrations peak in Arctic streams during peak snowmelt as they are flushed into freshwater systems from where soluble organic material has accumulated, through heterotrophic microbial activity underneath snowpacks, over the winter (Brooks et al. 1999). Because of this, studies conducted in late summer may provide different insights into nutrient uptake in streams as benthic algal communities would have had time to increase surface area cover, water temperature would be higher, nutrient-rich groundwater inputs would be more constant and lower stream flow would increase water-stream bed contact time. These probabilities could also explain the low uptake of nutrients in these streams during early summer. Increasing the study reach length could have resulted in greater uptake but this was not feasible as other meltwater inputs could have caused too large a dilution effect. 


\section{Environmental habitat conditions and effects on nutrient uptake rates}

The size of snowpacks that streams are sourced from are thought to play an important role on stream physicochemical habitat as different snowmelt proportions entering streams could alter water temperature and solute concentration. Snowpack size is thought to have a large influence on stream water temperature and channel stability due to a combination of spring floods and nivation processes, loosening and weathering sediment, increasing input to streams and increasing channel mobility. However, as neither nutrient uptake nor chl $a$ were significantly correlated with water temperature, hypothesis 3 was not accepted. This lack of correlation may be due to the small sample size of only five streams, and the small range of water temperature. Significant correlations between chl $a$ and water temperature have been found in other studies, indicating warmer water temperature enhances algal growth (Gíslason et al. 2000; Blaen et al. 2014). Chl $a$ biomass was markedly lower in this area of Greenland compared to other Arctic locations (e.g., Parker \& Huryn 2011; Blaen et al. 2014).

Channel stability was the most significant habitat difference between streams and was a function of source snowpack size. The role of higher channel stability was emphasized by the presence of moss in Kærelv, Grænseelv and Unnamed but not in Aucellaelv and Palnatokeelv. However, the low overall relative abundance of moss in all streams could partly explain the low nutrient uptake. Whilst Kærelv supported significantly higher biofilm biomass than the two low stability streams Aucellaelv and Palnatokeelv, hypothesis 4 was not accepted as biofilm biomass was lowest in Grænseelv. However, the low biomass in Grænseelv could be a function of the stream's low water temperature as opposed to a function of channel stability preventing biofilm growth. Biofilms were almost exclusively responsible for biological uptake in these systems but the surface area for biofilm uptake is smaller compared to moss (Rasmussen et al. 2011; Blaen et al. 2014). As such, even small biomasses of moss can contribute disproportionately to nutrient uptake. Channel stability differences were also highlighted for Aucellaelv and Palnatokeelv, where bed sediment consisted of a lower proportion of gravel compared to the other streams, and high disturbance events evident at Aucellaelv, which led to increased solute and sediment load in stream water (Docherty et al. 2017), creating different habitat conditions for biofilm colonization.

Organic matter was similar in quantity between all streams apart from Grænseelv (low percentage) and Unnamed (higher percentage). Organic matter is known to control carbon and nutrient budgets in streams (Webster \& Meyer 1997) through heterotrophic microbial activity (Meyer 1994), principally bacteria in fine benthic organic matter (Ellis et al. 1998). However, in this study, no direct correlation between organic matter biomass and nutrient uptake was found. This could be the result of variation in quality of organic matter between streams due to varying hydrology, geomorphology and disturbance regimes, and, therefore, variation in bacterial abundance (Findlay et al. 2002). All streams had higher organic matter than those included in a study in alpine Austria, where FBOM was typically less than $1 \%$ during summer (Schütz et al. 2001). These sites in north-east Greenland were comparable to open canopy streams from a study in north-west Wyoming, where FBOM ranged from 3\% to $13 \%$ (Johnson \& Tank 2009). Streams in Arctic regions overlaying permafrost typically have some of the highest organic matter content compared to streams globally (e.g., Dittmar \& Kattner 2003; Balcarczyk et al. 2009), although it has been found to be less biodegradable than organic matter in areas of less permafrost (Kawahigashi et al. 2004).

TOC was low in all streams (mean $2.24 \mathrm{mg} \mathrm{L}^{-1}$ ) apart from Aucellaelv $\left(7.76 \mathrm{mg} \mathrm{L}^{-1}\right)$ in comparison to streams in other Arctic regions, where an average of between 6.7 and $10.8 \mathrm{mg} \mathrm{L}^{-1}$ has been reported for streams in the Alaskan tundra (Peterson et al. 1986; Oswood et al. 1989) and between 1.2 and $30 \mathrm{mg} \mathrm{L}^{-1}$ had been reported for streams in boreal Finland (Kortelainen et al. 2006). Low FBOM, TOC and DOC availability can reduce nutrient uptake rates on a reach-scale because of less heterotrophic uptake associated with organic matter respiration and, as such, could have contributed to the low nutrient uptake rates seen in this study. DOC concentration has previously been found to be the main driver of nutrient uptake in streams in more temperate regions (Rodríguez-Cardona et al. 2016) and can be seen to be so in the case of Palnatokeelv in this study. The C: $\mathrm{N}$ ratio of stream organic matter may affect $\mathrm{N}$ retention because of linkages in the $\mathrm{N}$ and $\mathrm{C}$ biogeochemical cycles (Dodds et al. 2004). The implications of DOC concentration on nutrient uptake dynamics highlights the need for future studies in Arctic streams to understand the impact of carbon releases from thawing permafrost on stream nutrient dynamics.

\section{Summary and implications}

The streams in this study displayed both $\mathrm{N}$ and $\mathrm{P}$ limitation, whilst streams in Svalbard and Siberia proved to be primarily $\mathrm{N}$ limited (Blaen et al. 2014; Schade et al. 2016). The reach-scale $P$ limitation in Greenland seems to be primarily driven by 
heterotrophic uptake while the autotrophic biofilm production is mainly $\mathrm{N}$ limited. Low nutrient uptake rates in these streams are thought to be due to low water temperature resulting in low moss and algal densities and activities, combined with low nutrient concentration and DOC concentration to facilitate uptake. Although results are limited, DOC additions were shown to substantially increase $\mathrm{N}$ uptake. As heterotrophic processes are controlled by a combination of water temperature, dissolved nutrients, organic substrate availability, and both the quality and quantity of organic carbon (Tank \& Webster 1998), a combination of environmental variables need to be taken into consideration when considering future nutrient dynamics in Arctic streams in a changing climate.

Increased nutrient and DOC concentration in streams, as predicted with a changing climate, can impact the whole ecosystem, increasing algal growth and bacterial activity, converting the main carbon source from allochthonous to autochthonous, and shifting metabolism from heterotrophic to autotrophic (Peterson et al. 1985). However, the negative impact of high suspended sediment concentration on stream biota associated with decreased channel stability leads to large uncertainty as to future stream nutrient cycling in these systems.

This research provides the first insights into stream nutrient dynamics in north-east Greenland streams during peak snowmelt in early summer. Although there is high variation in climatological conditions both throughout the summer season and between years creating spatial and temporal variation on instream processes, this study can be used in the growing body of literature on Arctic stream nutrient cycling dynamics (Wollheim et al. 2001; Blaen et al. 2014; Diemer et al. 2015; Schade et al. 2016) to build an understanding that spans the entire Arctic region over a large temporal scale. The findings can be built upon in future in-depth studies into north-east Greenland stream nutrient cycling, as well as to gain insights into how a changing climate could impact these systems.

A warming climate is expected to increase active layer depth, releasing previously unavailable nutrients into streams along with labile DOC (O'Donnell et al. 2010). Our results indicate these nutrient inputs, coupled with higher water temperature, could increase biological activity in Arctic streams, enhancing nutrient uptake and retention. This increased activity will influence nutrient processing in the future and alter nutrient export to downstream regions (Blaen et al. 2014; Schade et al. 2016). However, further investigation is needed into the role of physical sorption compared to biological uptake in these streams, and into the predicted increases in suspended sediment concentration and the possible negative consequences this could have on algal communities. As well as this, given the importance of the $\mathrm{C}: \mathrm{N}$ ratio in organic matter for nutrient retention (Dodds et al. 2004), further studies to determine the importance of DOC for nutrient uptake in the region, as well as the proportions of DOC and nutrient release from thawing permafrost are needed to understand if stoichiometry will be maintained, and how nutrient uptake will be affected in the future.

\section{Acknowledgements}

Precipitation data from the Greenland Ecosystem Monitoring Programme were provided by Asiaq Greenland Survey, Nuuk, Greenland. Other climate data from the Greenland Ecosystem Monitoring Programme were provided by the Department of Bioscience, Aarhus University, Denmark, in collaboration with Department of Geosciences and Natural Resource Management, Copenhagen University, Denmark. The authors thank two anonymous reviewers for their comments that have helped improve this manuscript. The authors thank Biobasis, Geobasis and Zackenberg logistics for all of their field assistance. We thank Chantal Jackson for Fig. 1.

\section{Disclosure statement}

No potential conflict of interest was reported by the authors.

\section{Funding}

CD was funded through a Natural Environment Research Council studentship under grant agreement number NE/ L501712/1. Fieldwork was funded by the European Union Seventh Framework Programme (FP7/2007-2013) under grant agreement number 262693 (INTERACT) and the Carlsberg Foundation under grant 2013-01-0258.

\section{ORCID}

Catherine L. Docherty (D) http://orcid.org/0000-0003-48600059

Tenna Riis (D) http://orcid.org/0000-0003-2501-4444

David M. Hannah (D) http://orcid.org/0000-0003-1714-1240

\section{References}

Alexander R.B., Smith R.A. \& Schwarz G.E. 2000. Effect of stream channel size on the delivery of nitrogen to the Gulf of Mexico. Nature 403, 758-761.

Allen E.D. \& Spence D.H.N. 1981. The differential ability of aquatic plants to utilize the inorganic carbon supply in fresh waters. The New Phytologist 87, 269-283.

Balcarczyk K.L., Jones J.B. Jr., Jaffé R. \& Maie N. 2009. Stream dissolved organic matter bioavailability and composition. Biogeochemistry 94, 255-270.

Blaen P.J., Milner A.M., Hannah D.M., Brittain J.E. \& Brown L.E. 2014. Impact of changing hydrology on nutrient uptake in High Arctic rivers. River Research and Applications 30, 1073-1083.

Brooks P.D., Mcknight D.M. \& Bencala K.E. 1999. The relationship between soil heterotrophic activity, soil dissolved organic carbon (DOC) leachate, and catchment- 
scale DOC export in headwater catchments. Water Resource Research 35, 1895-1902.

Christiansen H.H., Sisgaard C., Humlum O., Rasch M. \& Hansen B. 2008. Permafrost and periglacial geomorphology at Zackenberg. In H. Meltofte et al. (eds.): HighArctic ecosystem dynamics in a changing climate. Advances in ecological research. Vol. 40. Pp. 151-174. Burlington: Academic Press.

Cross W.F., Wallace J.B., Rosemond A.D. \& Eggert S.L. 2006. Whole-system nutrient enrichment increases secondary production in a detritus-based ecosystem. Ecology 87, 1556-1565.

Diemer L.A., McDowell W.H., Wymore A.S. \& Prokushkin A. S. 2015. Nutrient uptake along a fire gradient in boreal streams of central Siberia. Freshwater Science 34, 1443-1456.

Dittmar T. \& Kattner G. 2003. The biogeochemistry of the river and shelf ecosystem of the Arctic Ocean: a review. Marine Chemistry 83, 103-120.

Docherty C.L., Hannah D.M., Riis T., Rosenhøj Leth S. \& Milner A.M. 2017. Large thermo-erosional tunnel for a river in northeast Greenland. Polar Science 14, 83-87.

Dodds W.K., Martí E., Tank J.L., Pontius J., Hamilton S.K., Grimm N.B., Bowden W.B., McDowell W.H., Peterson B.J., Valett H.M., Webster J.R. \& Gregory S. 2004. Carbon and nitrogen stoichiometry and nitrogen cycling rates. Oecologia 140, 458-467.

Ellis B.K., Stanford J.A. \& Ward J.V. 1998. Microbial assemblages and production in alluvial aquifers of the Flathead River, Montana, USA. Journal of the North American Benthological Society 17, 382-402.

Findlay S., Tank J., Dye S., Valley H.M., Mulholland P.J., McDowell W.H., Johnson S.L., Hamilton S.K., Edmond J., Dodds W.K. \& Bowden W.B. 2002. A cross-system comparison of bacterial and fungal biomass in detritus pools of headwater streams. Microbial Ecology 43, 55-66.

Finlay J., Neff J., Zimov S., Davydova A. \& Daydov S. 2006. Snowmelt dominance of dissolved organic carbon in high-latitude watersheds: implications for characterization and flux of river DOC. Geophysical Research Letters 33, L10401, doi: 10.1029/2006GL025754

Frey K.E. \& McClelland J.W. 2009. Impacts of permafrost degradation on Arctic river biogeochemistry. Hydrological Processes 182, 169-182.

Gíslason G.M., Ólafsson J.S. \& Adalsteinsson H. 2000. Life in glacial and alpine rivers in central Iceland in relation to physical and chemical parameters. Nordic Hydrology $31,411-422$.

Hansen B.U., Sigsgaard C., Rasmussen L., Cappelen J., Hinkler J., Mernild S.H., Petersen D., Tamstorf M.P., Rasch M. \& Hasholt B. 2008. Present-day climate at Zackenberg. In H. Meltofte et al. (eds.): High-Arctic ecosystem dynamics in a changing climate. Advances in ecological research. Vol. 40. Pp. 111-147. Burlington: Academic Press.

Hershey A., Bowden W., Deegan L., Hobbie J., Peterson B., Kipphut G., Kling G., Lok M., Merrit R. \& Miller M. 1997. The Kuparuk River: a long-term study of biological and chemical processes in an Arctic river. In A. Milner \& M. Oswold (eds.): Freshwaters of Alaska. Pp. 107-129. New York: Springer.

Hoellein T.J., Tank J.L., Kelly J.J. \& Rosi-Marshall E.J. 2010. Seasonal variation in nutrient limitation of microbial biofilms colonizing organic and inorganic substrata in streams. Hydrobiologia 649, 331-345.

Holmes R.M., McClelland J.W., Raymond P.A., Frazer B.B., Peterson B.J. \& Stieglitz M. 2008. Lability of DOC transported by Alaskan rivers to the Arctic Ocean. Geophysical Research Letters 35, L03402, doi: 10.1029/ 2007GLO32837

Johnson L.T. \& Tank J.L. 2009. Diurnal variations in dissolved organic matter and ammonium uptake in six open canopy streams. Journal of North American Benthological Society 28, 694-708.

Johnson L.T., Tank J.L. \& Arango C.P. 2009. The effect of land use on dissolved organic carbon and nitrogen uptake in streams. Freshwater Biology 54, 2335-2350.

Johnson L.T., Tank J.L. \& Dodds W.K. 2009. The influence of land use on stream biofilm nutrient limitation across eight North American biomes. Canadian Journal of Fisheries and Aquatic Sciences 66, 1081-1094.

Kawahigashi M., Kaiser K., Kalbitz K., Rodionov A. \& Guggenberger G. 2004. Dissolved organic matter in small streams along a gradient from discontinuous to continuous permafrost. Global Change Biology 10, 15761586.

Kelley A.M. \& Epstein H.E. 2009. Effects of nitrogen fertilization on plant communities of nonsorted circles in moist nonacidic tundra, Northern Alaska. Arctic, Antarctic, and Alpine Research 41, 119-127.

Kortelainen P., Mattsson T., Finér L., Ahtiainen M., Saukkonen S. \& Sallantaus T. 2006. Controls on the export of $\mathrm{C}, \mathrm{N}, \mathrm{P}$ and Fe from undisturbed boreal catchments, Finland. Aquatic Sciences 68, 453-468.

Lock M.A., Ford T.E., Hullar M.A.J., Kaufman M., Robie Vestal J., Volk G.S. \& Ventullo R.M. 1990. Phosphorus limitation in an Arctic river biofilm - a whole ecosystem experiment. Water Research 24, 1545-1549.

Madan N.J., Deacon L.J. \& Robinson C.H. 2007. Greater nitrogen and/or phosphorus availability increase plant species' cover and diversity at a High Arctic polar semidesert. Polar Biology 30, 559-570.

Mann P.J., Davydova A., Zimov N., Spencer R.G.M., Davydov S., Bulygina E., Zimov S. \& Holmes R.M. 2012. Controls on the composition and lability of dissolved organic matter in Siberia's Kolyma River basin. Journal for Geophysical Research-Biogeosciences 117, G01028, doi: 10.1029/2011JG001798

Martí E., Fonollà P., Schiller D.V., Sabater F., Argerich A., Ribot M. \& Riera J.L. 2009. Variation in stream C, N and $\mathrm{P}$ uptake along an altitudinal gradient: a space-for-time analogue to assess potential impacts of climate change. Hydrology Research 40, 123-137.

Mernild S.H., Liston G.E. \& Hasholt B. 2007. Snow-distribution and melt modelling for glaciers in Zackenberg river drainage basin, north-eastern Greenland. Hydrological Processes 21, 3249-3263.

Meyer J.L. 1994. The microbial loop in flowing waters. Microbial Ecology 28, 195-199.

O’Donnell J.A., Aiken G.R., Kane E.S. \& Jones J.B. 2010. Source water controls on the character and origin of dissolved organic matter in streams of the Yukon River Basin, Alaska. Journal of Geophysical Research-Biogeosciences 115, G03025, doi:10.1029/ 2009JG001153

Oswood M.W., Everett K.R. \& Schell D.M. 1989. Some physical and chemical characteristics of an Arctic beaded stream. Holarctic Ecology 12, 290-295.

Parker S.M. \& Huryn A.D. 2011. Effects of natural disturbance on stream communities: a habitat template analysis of Arctic headwater streams. Freshwater Biology 56, 1342-1357. 
Peterson B.J., Hobbie J.E. \& Corliss T.L. 1986. Carbon flow in a tundra stream ecosystem. Canadian Journal of Fisheries and Aquatic Sciences 43, 1259-1270.

Peterson B.J., Hobbie J.E., Hershey A.E., Lock M.A., Ford T.E., Robie Vestal J., McKinkey V.L., Hullar M.A.J., Miller M.C., Ventullo R.M. \& Volk G.S. 1985. Transformation of a tundra river from heterotrophy to autotrophy by addition of phosphorus. Science 229, 1383-1386.

Pfankuch D.J. 1975. Stream reach inventory and channel stability evaluation. Missoula, MT: US Department of Agriculture Forest Service, Region 1.

Pringle C.M., Paaby-Hansen R., Vaux P.D. \& Goldman C.R. 1986. In situ nutrient assays of periphyton growth in a lowland Costa Rican stream. Hydrobiologica 134, 207-213.

Rasmussen J.J., Baatrup-Pedersen A., Riis T. \& Friberg N. 2011. Stream ecosystem properties and processes along a temperature gradient. Aquatic Ecology 45, 231-242.

Rodríguez-Cardona B., Wymore A.S. \& McDowell W.H. 2016. DOC: $\mathrm{NO}_{3}{ }^{-}$ratios and $\mathrm{NO}_{3}{ }^{-}$uptake in forested headwater streams. Journal of Geophysical ResearchBiogeosciences 121, 205-217.

Ryan P.A. 1991. Environmental effects of sediment on New Zealand streams: a review. New Zealand Journal of Marine and Freshwater Research 25, 207-221.

Schade J.D., Seybold E.C., Drake T., Spawn S., Sobczak W.V., Frey K.E., Holmes R.M. \& Zimov N. 2016. Variation in summer nitrogen and phosphorus uptake among Siberian headwater streams. Polar Research 35, doi: 10.3402/polar. v35.24571

Schütz C., Wallinger M., Burger R. \& Füreder L. 2001. Effects of snow cover on the benthic fauna in a glacierfed stream. Freshwater Biology 46, 1691-1704.
Stendel M., Christiansen J.H. \& Petersen D. 2008. Arctic climate and climate change with a focus on Greenland. In H. Meltofte et al. (eds.): High-Arctic ecosystem dynamics in a changing climate. Advances in ecological research. Vol. 40. Pp. 13-43. Burlington: Academic Press.

Säwström C., Laybourn-Parry J., Granéli W. \& Anesio A. 2007. Heterotrophic bacterial and viral dynamics in Arctic freshwaters: results from a field study and nutrient-temperature manipulation experiments. Polar Biology 30, 1407-1415.

Tank J.L., Bernot M.J. \& Rosi-Marshall E.J. 2007. Nitrogen limitation and uptake. In F.R. Hauer \& G.A. Lamberti (eds.): Methods in stream ecology. 2nd edn. Pp. 213-238. Boston: Elsevier.

Tank J.L. \& Dodds W.K. 2003. Nutrient limitation of epilithic and epixylic biofilms in ten North American streams. Freshwater Biology 48, 1031-1049.

Tank J.L. \& Webster J.R. 1998. Interaction of substrate and nutrient availability on wood biofilm processes in streams. Ecology 79, 2168-2179.

Wallace J.B., Hutchens J.J. Jr. \& Grubaugh J.W. 2007. Transport and storage of FPOM. In F.R. Hauer \& G.A. Lamberti (eds.): Methods in stream ecology. 2nd edn. Pp. 249-271. Boston: Elsevier.

Webster J.R. \& Meyer J.L. 1997. Organic matter budgets for streams: a synthesis. Journal of the North American Benthological Society 16, 141-161.

Wollheim W.M., Peterson B.J., Deegan L.A., Hobbie J. E., Hocker B., Bowden W.B., Edwardson K.J., Arscott D.B., Hershey A.E. \& Finlay J. 2001. Influence of stream size on ammonium and suspended particulate nitrogen processing. Limnology and Oceanography 46, $1-13$. 